\title{
Pengaruh Kandungan Informasi Arus Kas, Dividend Payout Ratio Dan Economic Valued Added Terhadap Volume Perdagangan Saham Dengan Size Dan Growth Sebagai Variabel Kontrol
}

\author{
Pascalina V. S. Sesa ${ }^{1}$ \\ pascalinasesa@gmail.com \\ Jurusan Akuntansi, Fakultas Ekonomi dan Bisnis Universitas Cenderawasih
}

\begin{abstract}
This research aims to test the influence of information content on the company's cash flow statement, dividend payout ratio, economic value added, and use the proxiesof the sizeof the company ( size ) and the growth of the company (growth)as a control variable. The sample selection criteria in this study use purposive sampling. This research uses an analysis tool in the form of SPSS 21.0 which is used to test the research hypothesis in the form of quantitative data.

The results of this study suggest that: Investment cash flow information has a significant effect on stock trading volume.

Meanwhile, information on operating cash flow, fund cashflow, dividend payout ratio, and economic value added has no significant effect on the trading volume of the company'sshares with Size and Growth as variable controls have no effect on the volume of stock trading. The resultsof this research should increase knowledge for investors in using financial information for investment decision making by assessing the company's performance more accurately.
\end{abstract}

Keywords: Cash flow information; dividend payments; and economic value added; company size and company growth.

\begin{abstract}
Abstrak
Penelitian ini bertujuan untuk menguji pengaruh dari kandungan informasi pada laporan arus kas perusahaan, dividend payout ratio, economic value added, dan menggunakan proksi ukuran perusahaan (size) dan pertumbuhan perusahaan (growth) sebagai variabel kontrol. Informasi sangat dibutuhkan oleh investor dalam membuat keputusan investasi saat ini. Salah satu informasi yang penting bagi investor dalam membuat keputusan investasi yaitu kinerja perusahaan. Kinerja perusahaan go public, salah satunya dapat berupa volume perdagangan saham. Volume perdagangan saham, dan harga saham adalah alat yang digunakan untuk penilaian individual para investor dalam membuat keputusan untuk membeli atau menjual saham.

Kriteria pemilihan sampel dalam peneltian ini menggunakan teknik purposive sampling. Penelitian ini menggunakan alat analisis berupa SPSS 21.0 yang digunakan untuk menguji hipotesis penelitian.

Hasil penelitian ini menjukkan bahwa: Informasi arus kas investasi berpengaruh signifikan terhadap volume perdagangan saham. Hal tersebut memberikan sinyal positif kepada para investor tentang jaminannya di masa yang akan datang. Selain itu, hasil arus kas investasi yang berpengaruh signifikan terhadap volume perdagangan saham menunjukkan bahwa para investor memperhatikan hasil dari investasi jangka panjang maupun pendek serta penjualan aktiva tetap yang dilakukan perusahaan.

Sedangkan, Informasi arus kas operasi, arus kas pendanaan, dividend payout ratio, dan economic value added tidak berpengaruh signifikan terhadap volume perdagangan saham perusahaan manufaktur yang terdaftar di Bursa Efek Indonesia (BEI) dengan Size dan Growth sebagai variabel kontrol tidak berpengaruh terhadap volume perdagangan saham. Hal ini menunjukkan bahwa SIZE dan GROWTH tidak mengakui adanya keterikatan dengan AKO, AKI, AKP, DPR, dan EVA terhadap volume perdagangan saham. Hasil penelitian ini diharapkan mampu menambah pengetahuan bagi para investor dalam menggunakan informasi keuangan guna pengambilan keputusan untuk melakukan investasi di pasar modal. Dan diharapkan dapat menilai kinerja perusahaan yang berkaitan dengan keputusan investasi dalam lebih menggali informasi yang lebih akurat.
\end{abstract}

Kata Kunci: Informasi arus kas operasi, arus kas investasi, arus kas pendanaan, pembayaran deviden, dan nilai tambah ekonomi, ukuran perusahaan dan pertumbuhan perusahaan 


\section{Pendahuluan}

Pasar modal adalah media bagi penanaman modal oleh investor untuk menanamkan modalnya. Sehingga dalam membuat keputusan investasi, seorang investor akan sangat membutuhkan informasi. Informasi yang paling mendasar yang dibutuhkan oleh investor pada proses pengambilan keputusan investasi ialah kinerja perusahaan. Kinerja perusahaan yang go public dapat berupa return saham, volume perdagangan saham, serta kinerja keuangan lainnya. Salah satu sumber informasi yang sangat diperlukan oleh seorang investor yaitu laporan keuangan. Dimana semua perusahaan yang terdaftar di Bursa Efek Indonesia (BEI) setiap tahun dapat mempublikasikan laporan keuangannnya untuk menjelaskan dan memberikan informasi kepada stakeholder, khususnya investor, mengenai kinerja dan posisi keuangan perusahaan. Laporan keuangan terdiri dari laporan posisi keuangan atau neraca, laporan laba rugi, laporan ekuitas, laporan arus kas dan catatan atas laporan keuangan (Azhar et al., 2009).

Dalam Pernyataan Standar Akuntansi Keuangan (PSAK) No. 1 menjelaskan tujuan dari laporan keuangan yaitu untuk memberikan informasi tentang posisi keuangan perusahaan, kinerja dan arus kas perusahaan yang bermanfaat bagi sebagian besar kalangan pengguna laporan dalam rangka membuat keputusan-keputusan ekonomi serta menunjukkan pertanggungjawaban (Stewardship) manajemen atas penggunaan sumber-sumber daya yang dipercayakan kepada mereka. Selanjutnya PSAK No.2 menyatakan bahwa perusahaan harus menyusun laporan arus kas sebagai bagian integral dengan laporan keuangan. Menurut IAI (2009) hal ini dilatarbelakangi oleh adanya pergeseran tujuan pemakaian laporan keuangan yang semula ditekankan pada pertanggungjawaban sekarang lebih ditekankan sebagai dasar estimasi kemampuan perusahaan dalam meningkatkan kesejahteraan bagi stockholder.

Oleh karena laporan arus kas memiliki banyak informasi sehingga bisa digunakan oleh investor sebagai dasar pengambilan keputusan. Seperti informasi yang terkandung dalam arus kas aktivitas operasi, aktivitas investasi dan aktivitas pendanaan.

Dengan melihat informasi yang terkandung dalam laporan arus kas, para investor (penanam modal) dan calon investor akan yakin terhadap pilihan investasinya. Dan hal tersebut akan meningkatkan permintaan dan penawaran dalam perdagangan saham (Bastomi, 2014).

Kinerja perusahaan go public salah satunya dapat berupa volume perdagangan saham. Volume perdagangan saham dan harga saham adalah alat yang digunakan untuk penilaian individual para investor dalam membuat keputusan untuk membeli atau menjual saham. Seperti yang dijelaskan oleh signaling theory, pada umumnya informasi yang mengandung nilai positif diharapkan membuat pasar bereaksi yang ditunjukkan dengan adanya perubahan volume perdagangan saham pada waktu pengumuman telah diterima oleh pasar dan berlaku sebaliknya (Amethisa, 2008).

Sedangkan, volume perdagangan saham yang besar mengidentifikasikan bahwa saham tersebut aktif diperdagangkan. Untuk menilai perubahan volume perdagangan saham, maka diperlukannya informasi. Informasi tersebut akan memiliki makna atau nilai bagi investor jika keberadaan informasi tersebut menyebabkan investor melakukan transaksi di pasar modal. Investor biasanya akan mendasarkan keputusannya pada berbagai informasi yang dimilikinya, baik informasi yang tersedia di publik maupun informasi pribadi. Salah satu sumber informasi bagi investor yang sangat penting yaitu laporan keuangan yang lebih khusus untuk melihat pada informasi laporan arus kas perusahaan. Laporan arus kas merupakan laporan keuangan yang menyediakan informasi tentang arus kas suatu badan usaha yang berguna sebagai dasar menilai kemampuan badan usaha dalam menghasilkan kas atau setara kas serta menilai kebutuhan suatu badan usaha terhadap kas tersebut (Azhar et al, 2009).

Jika arus kas menghasilkan kenaikan kas, berarti investor melihat adanya kas masuk sehingga investor tertarik untuk melakukan pembelian saham perusahaan karena investor melihat adanya kinerja perusahaan yang baik dalam pengelolaan kas untuk meningkatkan kas masuk masa depan. Sebaliknya jika terjadi penurunan kas, investor akan mempertimbangkan kembali keputusan investasi yang dilakukannya. Dalam pengelolaan kas yang kurang maksimal menyebabkan investor mempertimbangkan untuk menjual atau melepas saham mereka.

Informasi laporan arus kas dikatakan mempunyai makna apabila dapat digunakan sebagai dasar pengambilan keputusan oleh investor. Apabila dengan dipublikasikannya laporan arus kas menyebabkan para investor di pasar modal bereaksi untuk melakukan pembelian atau penjualan sama yang selanjutnya tercermin dalma perubahan volume perdagangan saham, berarti laporan arus kas 
tersebut mempunyai kandungan informasi. Sebaliknya jika investor tidak bereaksi untuk membeli atau menjual saham maka dikatakan bahwa laporan arus kas tidak mempunyai kandungan informasi (Azhar et al, 2009).

Selain informasi laporan arus kas, pengumuman pembagian deviden merupakan salah satu faktor penting yang dapat mempengaruhi investor untuk berinvestasi. Hasil-hasil penelitian sebelumnya menunjukkan bahwa return saham dan harga saham bereaksi terhadap pengumuman deviden dilihat dari besarnya dividen yang dibagikan. Reaksi tersebut terjadi khususnya pada hari-hari disekitar tanggal ex-dividend. Dividen yang dibayarkan kepada para pemegang saham dalam penelitian ini yaitu di ukur dengan rasio dividend payout ratio. Pembayaran deviden tergantung pada kebijakan masingmasing perusahaan, sehingga memerlukan pertimbangan yang lebih serius dari manajemen perusahaan. Kebijakan deviden pada hakikatnya adalah menentukan porsi keuntungan yang akan dibagikan kepada para pemegang saham, dan yang akan ditahan sebagai bagian dari laba ditahan. Jika ada reaksi harga saham yang diakibatkan dari suatu pengumuman, maka bisa diartikan bahwa pengumuman itu mengandung informasi (Zahroh, 2009).

Economic value added merupakan metode yang digunakan sebagai cara untuk menghubungkan laba dengan dasar investasi (Ayuningrum, 2015). Economic value added merupakan penekanan pada penentuan besarnya jumlah cost of capital yang memperhitungkan biaya modal atas ekuitas. Manajer dalam memahami tujuan keuangan membutuhkan economic value added tanpa perlu menganalisa tahun-tahun sebelumnya.

Parameter kinerja perusahaan yang mendapat perhatian utama dari investor dan kreditor dari laporan keuangan adalah laba dan arus kas. Pada saat dihadapkan pada dua ukuran kinerja akuntansi keuangan tersebut, investor dan kreditor harus yakin bahwa ukuran kinerja yang menjadi fokus perhatian mereka adalah ukuran kinerja yang mampu menggambarkan kondisi ekonomi perusahan serta prospek pertumbuhan dimasa depan dengan lebih baik. Oleh karena itu, selain kedua ukuran kinerja tersebut investor dan kreditor juga perlu mempertimbangkan karakteristik keuangan setiap perusahaan. Karakteristik keuangan yang berbeda-beda antar perusahan menyebabkan relevansi angka-angka akuntansi yang tidak sama pada semua perusahaan. Ukuran (size) perusahaan dapat digunakan untuk mewakili karakteristik keuangan perusahaan (Hidayah, 2010).

Perusahaan yang besar yang sudah wellestablished akan lebih mudah memperoleh modal dipasar modal dibandingkan dengan perusahaan kecil. Kemudahan akses tersebut berarti perusahaan besar memiliki flesibilitas yang lebih besar pula. Sehingga ketika semakin banyak investor yang berniat membeli saham perusahaan yang berukuran besar maka harga saham perusahaan tersebut menjadi naik dan tingkat return saham juga meningkat dan mempengaruhi volume perdagangan saham perusahaan di pasar modal (Aisah \& Mandala, 2016).

Penelitian yang dilakukan oleh (Azhar et al., 2009) tentang Pengaruh Informasi Arus Kas dan Laba Akutansi terhadap Volume Perdagangan Saham pada Perusahaan Manufaktur yang Terdaftar di Bursa Efek Indonesia. Penelitian tersebut menunjukkan bahwa arus kas operasi memiliki pengaruh yang signifikan terhadap volume perdagangan saham, sementara laba akuntansi tidak memiliki pengaruh terhadap volume perdagangan saham, dan penelitian tersebut berhasil membuktikan adanya perbedaan volume perdagangan saham antara perusahaan dalam kondisi arus kas good news dan arus kas bad news.

Berbeda dari penelitian sebelumnya, penelitian lain yang dilakukan oleh (Sutriasih et al., 2013) tentang Pengaruh Informasi Laba Bersih, Arus Kas dan Publikasi Dividen pada Volume Perdagangan Perusahaan Manufaktur di Bursa Efek Indonesia. Penelitian tersebut menyatakan bahwa variabel informasi laba bersih, informasi arus kas dan publikasi dividen memiliki pengaruh positif signifikan terhadap volume perdagangan saham.

Penelitian yang dilakukan oleh (Ayuningrum, 2015) tentang Pengaruh Informasi Laporan Arus Kas, Dividend Payout Ratio (DPR) dan Economic Value Added (EVA) Terhadap Volume Perdagangan Saham Di Bursa Efek Indonesia. Penelitian tersebut menyatakan bahwa arus kas investasi dan Devidend Payout Ratio (DPR) mempunyai pengaruh yang signifikan dengan volume perdagangan saham, sementara arus kas operasi, arus kas pendanaan dan Economic Value Added (EVA) tidak mempunyai pengaruh yang signifikan terhadap Volume Perdagangan Saham. Dengan hasil penelitian terdahulu, maka penulis tertarik untuk meneliti kembali tentang Economic Value Added (EVA).

Berbeda dari penelitian yang dilakukan oleh (Safitri et al., 2018) tentang Pengaruh Informasi 
Laporan Arus Kas, Dividend Payout Ratio (DPR) dan Economic Value Added (EVA) Terhadap Volume Perdagangan Saham. Penelitian tersebut menyatakan bahwa variabel informasi arus kas memiliki pengaruh signifikan terhadap volume perdagangan saham, sementara variabel Dividend Payout Ratio (DPR) dan Economic Value Added (EVA) tidak berpengaruh signifikan terhadap volume perdagangan saham.

Penelitian yang dilakukan Sugiarto (2011) dan Purwaningrat dalam (Aisah \& Mandala, 2016), menujukkan bahwa ukuran perusahaan memiliki hubungan yang positif signifikan terhadap tingkat pengembalian saham. Penelitian lainnya yang dilakukan oleh Adiwiratama (2012) dalam (Aisah \& Mandala, 2016). hasil penelitiannya membuktikan bahwa ukuran perusahaan berpengaruh terhadap return saham. Sedangkan hasil penelitian lainnya juga membuktikan bahwa ukuran perusahaan tidak berhubungan terhadap return saham.

Hasil penelitian yang dilakukan oleh Norpratiwi (2007) dalam (Melati \& Nurwulandari, 2013) menunjukkan bahwa rasio Market to Book Value of Equity (MVEBVE) sebagai salah satu proksi Investment Opportunity Set (IOS) berbasis harga memiliki hubungan yang positif dengan abnormal return sesudah pelaporan kondisi keuangan perusahaan. Hal ini didukung oleh penelitiannya Ningrum (2011) dalam (Melati \& Nurwulandari, 2013) yang menunjukkan bahwa rasio MVEBVE memiliki pengaruh yang positif dan signifikan terhadap return saham. Semaking tinggi rasio MVEBVE dan tingkat pertumbuhan suatu perusahaan, maka semakin tinggi pula return saham perusahaan tersebut.

Penelitian ini melakukan pengujian terkait beberapa faktor yang mempengaruhi volume perdagangan saham yaitu informasi arus kas, Dividend Payout Ratio (DPR), Economic Value Added (EVA) dan menggunakan proksi ukuran perusahaan (size) dan pertumbuhan perusahaan (growth) sebagai variabel kontrol yang di karenakan investor yang menjadi pelaku utama dalam pergerakan volume perdagangan saham akan memilih-milih informasi yang dapat menguntungkan baginya di masa yang akan dating. Dalam mempertimbangkan keputusan investasinya investor juga investor cenderung memperkaya dirinya dengan berbagai informasi dari berbagai sumber sehingga dapat menjadi dasar yang kuat dalam mengambil suatu keputusan investasi. Perusahaan manufaktur di gunakan sebagai sampel dalam penelitian ini karena perusahaan manufaktur adalah industry yang terbesar di Bursa Efek Indonesia dengan melihat tingkat aktivitasnya yang banyak.

Penelitian ini juga bertujuan untuk menganalisis pengaruh dari kandungan informasi pada laporan arus kas perusahaan, dividend payout ratio, economic value added, dan menggunakan proksi ukuran perusahaan (size) dan pertumbuhan perusahaan (growth) sebagai variabel kontrol. Hasil penelitian ini diharapkan mampu menambah pengetahuan bagi para investor dalam menggunakan informasi keuangan guna pengambilan keputusan untuk melakukan investasi di pasar modal, sehingga dapat meminimalisir risiko yang kemungkinan akan terjadi sebagai dampak atau akibat dalam pembelian dan penjualan saham di pasar modal.

\section{Tinjauan Pustaka}

\subsection{Signaling Theory}

Teori sinyal adalah tindakan perusahaan dalam memberi sinyal kepada investor tentang bagaimana manajemen memandang prospek perusahaan. Sinyal ini berupa informasi mengenai apa yang sudah dilakukan oleh manajemen untuk merealisasikan keinginan pemilik (Bringham, 2014). Informasi yang disajikan oleh perusahaan digunakan oleh investor untuk pengambilan keputusan investasi. Pada saat perusahaan memberikan informasi, pelaku pasar terlebih dahulu menginterpretasikan dan menganalisis informasi tersebut sebagai good news atau bad news. Jika informasi tersebut dianggap sebagai sinyal baik, maka investor akan tertarik untuk melakukan perdagangan saham, dengan demikian pasar akan bereaksi yang tercermin melalui perubahan dalam volume perdagangan saham (Suwardjono, 2010) dalam (Rajagukguk et al., 2019).

Teori sinyal menjelaskan bahwa sinyal dilakukan oleh manajer untuk mengurangi asimetri informasi. Dalam asimetri informasi, manajer lebih banyak mengetahui informasi tentang kondisi dan prospek masa depan perusahaan dibandingkan dengan pemilik perusahaan. Dalam signaling theory, menjelaskan bahwa umumnya informasi yang mengandung nilai positif diharapkan membuat pasar bereaksi yang ditunjukkan dengan adanya perubahan volume perdagangan saham pada waktu pengumuman telah diterima oleh pasar dan berlaku sebaliknya (Amethisa, 2008). 
Selain itu, menurut (Sutriasih et al., 2013) dan (Bastomi, 2014) menjelaskan bahwa teori sinyal akan menggambarkan tentang kebutuhan investor akan informasi yang lengkap, tepat waktu dan akurat yang akan digunakan sebagai dasar dalam pengambilan keputusan ivestasi. Informasi yang diterima pasar dapat berupa sinyal buruk (bad news) atau sinyal baik (good news). Jika suatu informasi mengandung nilai positif maka diasumsikan pasar akan memiliki reaksi pada saat informasi tersebut ditangkap atau diterima oleh pasar.Jika informasi yang diumumkan memberikan sinyal yang baik bagi investor maka akan terjadi perubahan pada harga saham, di mana harga saham akan meningkat dan hal sebaliknya akan terjadi jika informasi yang diumumkan memberikan sinyal yang buruk (Sutriasih et al., 2013).

Laporan keuangan tahunan merupakan salah satu jenis informasi yang dipublikasikan oleh perusahaan yang dapat menjadi sinyal atau tanda bagi pihak luar perusahaan terutama bagi investor. Informasi yang diungkapkan dan disediakan dalam laporan keuangan tahunan dapat berupa informasi akuntansi yang menyediakan informasi yang memiliki kaitan dengan laporan keuangan dan informasi non-akuntansi yaitu informasi yang tidak memiliki kaitan dengan laporan keuangan. Dalam laporan tahunan seharusnya terdapat informasi yang relevan serta mengungkapkan informasi yang dianggap atau dipandang penting untuk diketahui oleh pengguna laporan baik bagi pihak dalam maupun bagi pihak luar (Novalia et al., 2016).

Faktor-faktor seperti informasi arus kas, pembayaran dividen, dan economic value added serta faktor lain seperti ukuran perusahaan dan pertumbuhan perusahaan merupakan suatu pengungkapan informasi akuntansi yang signifikan yang dipublikasikan oleh perusahaan sebagai pengumuman yang akan memberikan sebuah sinyal bagi investor pada saat mengambil keputusan investasi yang berdampak pada tanggapan atau reaksi pasar. Reaksi pasar digambarkan dengan adanya pergerakan harga saham saat informasi sedang diumumkan dan seluruh pelaku pasar telah menerima informasi tersebut, dan akan terlihat pada volume perdagangan saham tahun berikutnya (Sutriasih et al., 2013).

Menurut (Safitri et al., 2018), Volume perdagangan dapat diartikan sebagai total lembar saham yang diperdagangkan pada hari tertentu. Volume perdagangan yang tinggi atau besar menunjukkan bahwa saham yang aktif berarti sedang diminati atau digemari oleh investor. Informasi laporan arus kas di dalamnya terdapat saldo kas bersih baik dari operasi, investasi dan pendanaan yang jika semakin tinggi, maka diharapkan investor dapat yakin bahwa perusahaan dapat menghasilkan atau memperoleh kas yang cukup untuk menjaga dan memelihara kemampuan perusahaan dalam melunasi pinjaman, membayar atau mengalokasikan dividen dan melakukan investasi yang baru tanpa bergantung atau mengandalkan dari sumber pendanaan yang berasal dari luar, sehingga hal ini akan mengakibatkan volume perdagangan saham meningkat (Safitri et al., 2018).

\subsection{Agency Theory}

Teori agensi merupakan teori yang digunakan perusahaan dalam mendasari praktik bisnisnya, dalam teori agensi dijelaskan bahwa hubungan antara manajemen perusahaan (agent) dan pemegang saham (principal). Hubungan keagenan adalah sebagai suatu kontrak antara satu atau lebih pihak yang mempekerjakan orang lain untuk melakukan suatu jasa untuk kepentingan mereka. dengan demikian, teori ini mengindikasikn adanya kepentingan pada setiap pihak yang ada diperusahaan untuk mecari tujuan (Jensen dan Meckling, 1976) dalam (Safitri et al., 2018).

Persoalan keagenan timbul karena pemisahan antara pemilik (principal) yang mendelegasikan wewenang kepada manajer (agent). Principal menginginkan pengembalian yang sebesar-besarnya dan secepatnya atas investasi yang salah satunya dicerminkan dengan kenaikan porsi deviden dari tiap saham yang dimiliki. Agent menginginkan kepentingannya diakomodir dengan pemberian kompensasi, bonus atas insentif yang "memadai" dan sebesar-besarnya atas kinerjanya (Sutriasih et al, 2013).

Dalam hubungan keagenan manajer memiliki asimetris informasi terhadap pihak eksternal atau luar perusahaan, seperti investor dan kreditur, hal ini sebagai akibat dari manajer sebagai pihak yang memiliki akses dan kewenangan langsung terhadap informasi yang ada dalam perusahaan, (Novalia et al., 2016). Teori Agensi dapat diterapkan pada kegiatan operasional perusahaan 
contohnya seperti strategi akuisisi dan diversivikasi, pembiayaan, pemberian kompensasi, struktur keprincipalan, hubungan dewan direksi dan inovasi (Ang et al., 2000 ; Barnea et al., 1985 ; Bergen et al., 1992) dalam (Kurniawansyah \& Kurnianto, 2018).

Jika masing-masing pihak yang berhubungan adalah pemaksimalan kegunaan (utility maximize), maka hal ini dapat dijadikan alasan bahwa manajer tidak selalu bertindak yang terbaik bagi kepentingan pemilik (Taswan, 2010:217) dalam (Sutriasih et al., 2013). Principal menginginkan agent untuk bekerja dan memberikan suatu jasa atau pengembalian yang secepatnya dengan jumlah yang sebesar-besarnya atas suatu investasi, hal ini dapat digambarkan dengan naiknya angka pembagian dividen dari setiap saham yang dimiliki. Agent menginginkan kepentingannya didukung dengan pemberian kompensasi, bonus atau insentif yang "memadai" dan sebesar-besarnya atas kinerjanya. Namun, agent lebih memilih menghindari risiko sebab tidak dapat membuat variasi pekerjaannya, sementara principal dapat menjadi pihak yang dapat menetralkan risiko sebab dapat atau mampu membuat variasi investasi (Kurniawansyah \& Kurnianto, 2018).

Principal menilai prestasi agent berdasarkan kemampuannya memperoleh laba yang lebih tinggi atau besar lagi untuk dialokasikan atau disalurkan pada pembagian dividen. Semakin tinggi laba, dividen akan semakin besar, maka agent akan dianggap berhasil dan memiliki hasil kinerja yang bagus atau baik sehingga pantas dan layak untuk mendapatkan insentif yang lebih tinggi. Bentuk keberhasilan agent dapat dilihat secara transparan melalui pertanggung jawabannya berupa laporan keuangan yang diajukan (Sutriasih et al., 2013).

\subsection{Penelitian Terdahulu dan Pengembangan Hipotesis}

Penelitian terkait kandungan informasi laporan arus kas, dividend payout ratio, economic value added terhadap volume perdagangan saham telah banyak dilalukan di Indonesia akan tetapi selain masih terdapat ketidakkonsistenan dari hasil penelitian terdahulu, juga penelitian yang terkait dengan ukuran perusahaan (size) dan pertumbuhan perusahaan (growth) sebagai variabel kontrol terhadap volume perdagangan masih sangat kurang. Sehingga, seiring dengan perkembangan dunia pasar modal dan investasi maka investor sebagai pelaku utama dalam pergerakan volume perdagangan saham, investor pun memilih-milih informasi yang dapat menguntungkan baginya di masa yang akan dating. Juga dalam mempertimbangkan keputusan investasinya investor pun tidak hanya melihat satu informasi saja bahkan melihat dari informasi yang berbeda-beda jenis sumbernya, sebab dalam satu jenis sumber informasi terkadang investor tidak cukup puas menjadikannya alasan sebagai pertimbangan keputusan investasinya.

Hasil penelitian terkait informasi arus kas dan laba akuntansi terhadap volume perdagangan saham telah di lakukan oleh beberapa peneliti yang menunjukkan hasil yang berbeda. Seperti penelitian yang di lakukan oleh (Azhar et al, 2009) yang membuktikan bahwa adanya pengaruh signifikan arus kas operasi terhadap volume perdagangan saham, sedangkan laba akuntansi tidak mempunyai pengaruh terhadap volume perdagangan saham, dan penelitian tersebut berhasil membuktikan adanya perbedaan volume perdagangan saham antara perusahaan dalam kondisi arus kas good news dan arus kas bad news. Sedangkan, hasil yang berbeda menunjukkan bahwa Informasi laba akuntansi tidak memiliki pengaruh signifikan positif terhadap volume perdagangan saham, arus kas operasi memiliki pengaruh signifikan positif terhadap volume perdagangan saham, arus kas investasi memiliki pengaruh signifikan negatif terhadap volume perdagangan saham, dan arus kas pendanaan memiliki pengaruh signifikan negatif terhadap volume perdagangan saham (Hilma, 2014).

Hasil penelitian lainnya yang terkait Arus kas dan laba akuntansi terhadap volume perdagangan yang dilakukan oleh (Afrinta et al, 2013) membuktikan bahwa total arus kas dan arus kas investasi memiliki pengaruh yang signifikan terhadap volume perdagangan. Sedangkan, pengujian yang sama terkait arus kas operasi dan arus kas pendanaan terhadap volume perdagangan menunjukkan bahwa arus kas operasi dan arus kas pendanaan tidak memiliki pengaruh yang signifikan terhadap volume perdagangan. Tidak adanya pengaruh yang signifikan lebih disebabkan oleh kebijakan beberapa perusahaan yang melakukan pembayaran dividen kas, pembayaran hutang bank maupun kepada pihak lain secara besar.

Hasil penelitian yang dilakukan oleh (Bastomi, 2014) menunjukkan bahwa aruskas aktivitas 
investasi berpengaruh terhadap volume perdagangan saham, sedangkan arus kas aktivitas operasi, aktivitas pendanaan dan total arus kas tidak berpengaruh terhadap volume perdagangan saham.

Sedangakan penelitian lainnya yang dilakukan terkait informasi laporan arus kas, dividend payout ratio, economic value added terhadap volume perdagangan saham menunjukkan bahwa Arus kas investasi dan Devidend Payout Ratio (DPR) mempunyai pengaruh yang signifikan dengan volume perdagangan saham, sedangkan arus kas operasi, arus kas pendanaan dan Economic Value Added (EVA) tidak mempunyai pengaruh yang signifikan terhadap Volume Perdagangan Saham (Ayuningrum, 2013). Hasil yang sama juga membuktikan bahwa Economic value added dan current ratio tidak memiliki pengaruh yang signifikan terhadap trading volume activity, sedangkan dividend payout ratio memiliki pengaruh yang signifikan terhadap trading volume activity (Amethisa, 2008).

Sedangkan hasil penelitian lain menunjukkan bahwa Variabel informasi arus kas memiliki pengaruh signifikan terhadap volume perdagangan saham, sedangkan variabel informasi Dividend Payout Ratio (DPR) dan Economic Value Added (EVA) tidak memiliki pengaruh yang signifikan terhadap volume perdagangan saham (Safitri et al., 2018). Hasil serupa terkait Dividend Payout Ratio (DPR) yang meningkat dan Dividend Payout Ratio (DPR) yang menurut terhadap harga saham tidak memiliki pengaruh (Anggraini et al., 2013). Hasil penelitian lainnya juga menunjukkan bahwa terdapat pengaruh signifikan antara laba bersih, arus kas dan dividen tunai terhadap volume perdagangan saham pada sektor baran dan konsumsi secara simultan (Susilowati \& Sinaga, 2019). Penelitian lainnya yang dilakukan oleh (Zahroh, 2009) menunjukkan bahwa dividend payout ratio dan ukuran perusahan (size) memiliki pengaruh yang signifikan terhadap return saham. Sedangkan, hasil penelitian lainnya menunjukkan bahwa ukuran perusahaan tidak memiliki pengaruh yang signifikan terhadap return saham perusahaan (Aisah \& Mandala, 2016).

Hasil serupa juga menunjukkan bahwa ukuran perusahan (size) berpengaruh negative terhadap expected return saham. Sedangkan, aktivitas perdagangan saham (volume) berpengaruh signifikan terhadap expected return saham (Hidayah, 2010). Hasil penelitian yang di lakukan oleh (Rajagukguk et al., 2019) menunjukkan bahwa ukuran perusahan memiliki pengaruh positif terhadap nilai perusahaan.

Hasil penelitian juga menunjukkan bahwa tidak terjadi peningkatan harga yang signifikan sebelum dan sesudah stock split pada perusahaan tidak bertumbuh, tetapi justru terjadi penurunan volume perdagangan saham dan abnormal return saham sebelum dan sesudah stock split pada perusahaan tidak bertumbuh. Hal tersebut menunjukkan bahwa pada dasarnya investor cenderung tidak memberikan reaksi yang positif terhadap stock split yang dilakukan oleh perusahaan tidak bertumbuh, bahwa investor cnderung bereaksi negatif terhadap stock split yang dilakukan oleh perusahaan tidak bertumbuh. Hasil penelitian juga menunjukkan bahwa harga, volume perdagangan saham dan abnormal return saham sesudah stock split pada perusahaan bertumbh lebih besar secara signifikan dari pada harga, volume perdagangan saham dan abnormal return saham sesudah stock split pada perusahan tidak bertumbuh. Hal tersebut menunjukkan bahwa investor memberikan reaksi yang lebih baik terhadap stock split yang dilakukan oleh perusahan bertumbuh daripada stock split yang dilakukan oleh perusahaan tidak bertumbuh (Melati \& Nurwulandari, 2013). Dengan demikian hipotesis yang dapat dirumuskan sebagai berikut:

H1a : Arus kas operasi berpengaruh terhadap volume perdagangan saham.

$\mathrm{H} 1 \mathrm{~b}$ : Arus kas investasi berpengaruh terhadap volume perdagangan saham.

$\mathrm{H} 1 \mathrm{c}$ : Arus kas pendanaan berpengaruh terhadap volume perdagangan saham.

H2 : Dividend Payout Ratio (DPR) berpengaruh terhadap volume perdagangan saham.

H3 : Economic Value Added (EVA) berpengaruh terhadap volume perdagangan saham.

\section{Metode Penelitian}

Penelitian ini adalah penelitian bersifat asosiatif yang memiliki tujuan untuk menguji pengaruh antara dua atau lebih variabel, yaitu untuk menguji pengaruh dari variabel independen yaitu kandungan informasi laporan arus kas (arus kas operasi, arus kas investasi, arus kas pendanaan), dividend payout ratio, dan economic value added terhadap variabel dependen yaitu volume perdagangan saham dengan ukuran perusahaan (size) dan pertumbuhan perusahaan (growth) sebagai variabel kontrol. Penelitian ini menggunakan jenis data dengan pendekatan kuantitatif yang mana menggunakan data sekunder yaitu data time series yang dikumpulkan dari waktu ke waktu pada satu 
objek. Dengan menggunakan data sekunder dari perusahaan manufaktur yang terdaftar di Bursa Efek Indonesia (BEI) yang berupa laporan keuangan (auditan) dan tahunan perusahaan yang dipublikasian pada tahun 2014, 2015, 2016, 2017, 2018 dan 2019 yang bersumber dari website BEI melalui browsing internet di www.idx.co.id. Data volume perdagangan saham yang didalamnya terdapat jumlah saham yang diperdagangkan bersumber dari website www.finance.yahoo.com selama tahun berjalan pada tanggal dan bulan terakhir.

Kriteria pemilihan sampel dalam peneltian ini menggunakan teknik purposive sampling yaitu suatu teknik pengambilan sampel yang disesuaikan dengan kriteria-kriteria tertentu. Berikut ini adalah beberapa kriteria sampel dalam penelitian ini:

1. Perusahaan manufaktur yang terdaftar di Bursa Efek Indonesia (BEI) pada tahun 20142019.

2. Perusahaan manufaktur yang telah menerbitkan dan mempublikasikan laporan keuangan tahunan secara lengkap pada tahun 2014-2018 serta melaporkan dalam mata uang rupiah.

3. Perusahaan manufaktur yang mempublikasikan dividen pada tahun 2014-2019.

4. Perusahaan manufaktur yang memperhitungkan beban bunga per tahun dalam laporan keuangan pada tahun 2014-2019.

5. Perusahaan manufaktur yang memiliki informasi ukuran perusahaan dan pertumbuhan perusahaan dalam laporan keuangannya pada tahun 2014-2019.

Penelitian ini menggunakan alat analisis berupa SPSS 21.0 yang digunakan untuk menguji hipotesis yang ada, beserta untuk menghasilkan data uji statistic deskriptif, uji asumsi klasik, anda analisis regresi berganda. Analisis data ini merupakan proses pembentukan data ke dalam bentuk yang sederhana agar mudah dibaca dan diinterpretasikan. Prosedur pengolahan data yang dilakukan dalam penelitian ini dimulai dari memilah data terlebih dahulu ke dalam variabel-variabel yang akan digunakan dalam penelitian ini. Dari hasil operasioanal variabel yang akan diuji, nilai variabel tersebut dimasukkan dalam program SPSS 21.0.

Metode analisis yang dipakai dalam penelitian ini adalah Analisis Kuantitatif yaitu dengan menggunakan teknik analisis berupa Analisis Regresi Linear Berganda. Analisis regresi linear berganda dilakukan untuk mengetahui adanya hubungan antara variabel dependen dengan variabelvariabel indepdenden dan variabel kontrolnya. Dalam penelitian ini variabel yang dimasukkan adalah 1 variabel dependen dan 5 variabel independen yang manadiformulasikan sebagai berikut:

$$
Y=a+b 1 X 1+b 2 X 2+b 3 X 3+b 4 X 4+b 5 X 5+e
$$

Keterangan:

$\mathrm{Y}=$ Volume perdagangan saham

$\mathrm{a}=$ Konstanta

b1, b2, b3, b4, b5, b6 = Koefisien regresi untuk X1, X2, X3, X4, X5, X6

$\mathrm{X} 1=$ Arus kas operasi

$\mathrm{X} 2=$ Arus kas investasi

$\mathrm{X} 3=$ Arus kas pendanaan

$\mathrm{X} 4=$ Dividend payout ratio

$\mathrm{X} 5$ = Economic Value Added

$e=$ Error

\section{Hasil Dan Pembahasan}

\section{Gambaran Umum Data Penelitian}

Populasi dalam penelitian ini adalah perusahaan manufaktur yang terdaftar di Bursa Efek Indonesia (BEI) yang berjumlah 162 perusahaan. Pengambilan sampel dilakukan dengan menggunakan teknik purposive sampling sehingga didapatkan jumlah 39 perusahaan sebagai sampel dengan pengamatan selama enam tahun, sehingga jumlah sampel yand didapatkan 234 sampel. Dari total 234 sampel tersebut terdapat data outliner sebanyak 25 data yang harus dikeluarkan dari sampel, sehingga jumlah data yang dapat diolah sebanyak 209 data. 
Tabel 1: Gambaran Umum Data Penelitian

\begin{tabular}{lc}
\hline \multicolumn{1}{c}{ Keterangan } & Jumlah Sampel \\
\hline $\begin{array}{l}\text { 1. Perusahaan manufaktur yang terdaftar di Bursa Efek Indonesia (BEI) } \\
\text { pada tahun 2014-2019 }\end{array}$ & $\mathbf{1 6 2}$ \\
$\begin{array}{l}\text { 2. Perusahaan manufaktur yang tidak menerbitkan dan mempublikasikan } \\
\text { laporan keuangan tahunan secara lengkap pada tahun 2014-2019 serta }\end{array}$ & $\mathbf{( 5 5 )}$ \\
$\begin{array}{l}\text { tidak melaporkan dalam mata uang rupiah } \\
\text { 3. Perusahaan manufaktur yang tidak mempublikasikan dividen pada tahun }\end{array}$ & $\mathbf{( 6 4 )}$ \\
2014-2018 & $\mathbf{( 4 )}$ \\
4. Perusahaan manufaktur yang tidak memperhitungkan beban bunga per & $\mathbf{3 9}$ \\
tahun dalam laporan keuangan pada tahun 2014-2019 & $\mathbf{2 3 4}$ \\
Jumlah Perusahaan yang Dijadikan Sampel & $\mathbf{( 2 5 )}$ \\
Jumlah Sampel Hasil Purposive Sampling (39x6) & $\mathbf{2 0 9}$ \\
Jumlah Data Outlier & \\
\hline
\end{tabular}
Sumber: Data sekunder diolah, 2020

\section{Statistik Deskriptif Perusahaan}

Tabel 2: Hasil Uji Statistik Deskriptif

\begin{tabular}{lrrrrr}
\hline & N & \multicolumn{1}{c}{ Minimum } & \multicolumn{1}{c}{ Maximum } & \multicolumn{1}{c}{ Mean } & \multicolumn{1}{c}{ Std. Deviation } \\
\hline AKO & 209 & $-162794,51$ & 26290000,00 & 2016639,9438 & 4170804,31337 \\
AKI & 209 & $-14941000,00$ & 333591,00 & $-978786,5360$ & 2078822,94832 \\
AKP & 209 & $-13785001,00$ & 3466656,00 & $-867531,9906$ & 2441256,69966 \\
DPR & 209 &,- 02631 & 2,24869 &, 4585373 &, 33739046 \\
EVA & 209 & $-9038550,21$ & 4327568,54 & 29776,7556 & 1126163,83199 \\
SIZE & 209 & 11,12640 & 14,47077 & 12,6242644 &, 72630929 \\
GROW & 209 &,- 14809 & 1,03052 &, 1194301 &, 15569378 \\
TVA & 209 &, 00001 & 1,78969 &, 1577911 &, 26433818 \\
Valid N (listwise) & 209 & & & & \\
\hline
\end{tabular}

Sumber: Data sekunder diolah, 2020

1. Nilai rata-rata AKO yaitu sebesar Rp. 2,016,639.9438, nilai AKO terendah yaitu sebesar -Rp. 162.794.51, sedangkan nilai AKO tertinggi yaitu sebesar Rp. 2.6290.000.00. Standar deviasi untuk AKO diperoleh sebesar 4.170.804.313.37.

2. Nilai rata-rata AKI sebesar -Rp.978.786.536.0, nilai AKI terendah yaitu -Rp. 14.941.000.00, sedangkan nilai AKI tertinggi yaitu Rp.333.591.00. Standar deviasi untuk AKI diperoleh sebesar 2.078.822.948.320.

3. Nilai rata-rata AKP yaitu sebesar -Rp. 8.675.319.906, nilai AKP terendah yaitu Rp.13.785.001.00, sedangkan nilai tertinggi AKP yaitu sebesar Rp.3.466.656.00. Standar deviasi untuk AKP diperoleh sebesar 2.441.256.699.660.

4. Nilai rata-rata DPR selama tahun 2014 sampai dengan 2019 yaitu sebesar 0,4585373 atau 46\%, nilai DPR terendah yaitu sebesar 0,2631 atau 26\%\%. Sedangkan nilai DPR tertinggi yaitu sebesar 2,24869 atau 224\%. Standar deviasi yang diperoleh DPR yaitu sebesar 0,33739046 atau 33\%.

5. Nilai rata-rata EVA pada perusahaan manufaktur selama tahun 2014 sampai dengan 2019 yaitu sebesar -Rp. 29.776.755.60. Nilai EVA terendah selama tahun pengamatan yaitu sebesar Rp.9.038.550.21, sedangkan nilai EVA tertinggi yaitu sebesar Rp.4.327.568.54. Berdasarkan hasil pengolahan data EVA, maka diperoleh standar deviasi yaitu sebesar 1.126.163.831.990.

6. Nilai rata-rata SIZE selama tahun pengamatan yaitu sebesar 126.242.644, nilai SIZE terendah yaitu sebesar 11,12640 sedangkan nilai SIZE tertinggi yaitu sebesar 14.47077. Berdasarkan hasil pengolahan data SIZE, maka diperoleh standar deviasi yaitu sebesar 0.72630929 . 
7. Nilai rata-rata GROW selama tahun pengamatan yaitu sebesar 0.1194301 , nilai GROW terendah yaitu sebesar 0,14809sedangkan nilai GROW tertinggi yaitu sebesar 1,03052. Berdasarkan hasil pengolahan data GROW, maka diperoleh standar deviasi yaitu sebesar 0,15569378.

8. Nilai rata-rata TVA selama tahun pengamatan yaitu sebesar 01577911, nilai terendah TVA yaitu sebesar 0,00001, sedangkan nilai TVA tertinggi yaitu sebesar 1,78969. Standar deviasi yang diperoleh TVA yaitu sebesar 0,26433818

\section{Hasil Uji Asumsi Klasik}

\section{Hasil Pengujian Normalitas}

Tabel 3: Hasil Uji Normalitas

\begin{tabular}{llr}
\hline \multicolumn{2}{c}{ Parameter } & Unstandardized Residual \\
\hline N & & 209 \\
Normal Parameters ${ }^{\text {a,b }}$ & Mean &, 0000000 \\
& Std. Deviation & 1,15084557 \\
& Absolute &, 048 \\
Most Extreme Differences & Positive &, 037 \\
& Negative &,- 048 \\
Kolmogorov-Smirnov Z & &, 698 \\
Asymp. Sig. (2-tailed) & &, 714 \\
\hline
\end{tabular}

Sumber: Data sekunder diolah, 2020

Berdasarkan hasil uji Kolmogorov-Smirnov, dapat dilihat nilai signifikansinya sebesar 0,714. Variabel-variabel dalam uji Kolmogorov-Smirnov yang mempunyai Asymp. Sig. (2-tailed) di atas tingkat signifikan sebesar 0,05 diartikan bahwa variabel-variabel tersebut memiliki distribusi yang normal, dan sebaliknya. Hal tersebut menunjukkan bahwa secara statistik, residual data yang digunakan dalam model regresi memiliki distribusi yang normal.

\section{Hasil Pengujian Multikolonieritas}

Tabel 4: Hasil Uji Multikolinearitas

\begin{tabular}{|c|c|c|c|}
\hline \multirow{2}{*}{\multicolumn{2}{|c|}{ Model }} & \multicolumn{2}{|c|}{ Collinearity Statistics } \\
\hline & & \multirow[t]{2}{*}{ Tolerance } & \multirow[t]{2}{*}{ VIF } \\
\hline \multirow{8}{*}{1} & (Consta & & \\
\hline & $\mathrm{AKO}$ &, 532 & 1,878 \\
\hline & AKI & , 440 & 2,272 \\
\hline & AKP & ,430 & 2,326 \\
\hline & DPR & ,929 & 1,077 \\
\hline & EVA & ,787 & 1,270 \\
\hline & SIZE & ,464 & 2,155 \\
\hline & GROW & ,944 & 1,059 \\
\hline
\end{tabular}

Sumber: Data sekunder diolah, 2020

Berdasarkan hasil pengujian multikolonieritas, maka dapat dilihat bahwa setiap variabel memiliki nilai tolerance lebih dari 0,1 dan nilai VIFnya tidak melebihi 10. Hal tersebut menunjukkan bahwa tidak terdapat korelasi antara enam variabel independen yang digunakan dalam penelitian. 


\section{Hasil Pengujian Heteroskedastisitas}

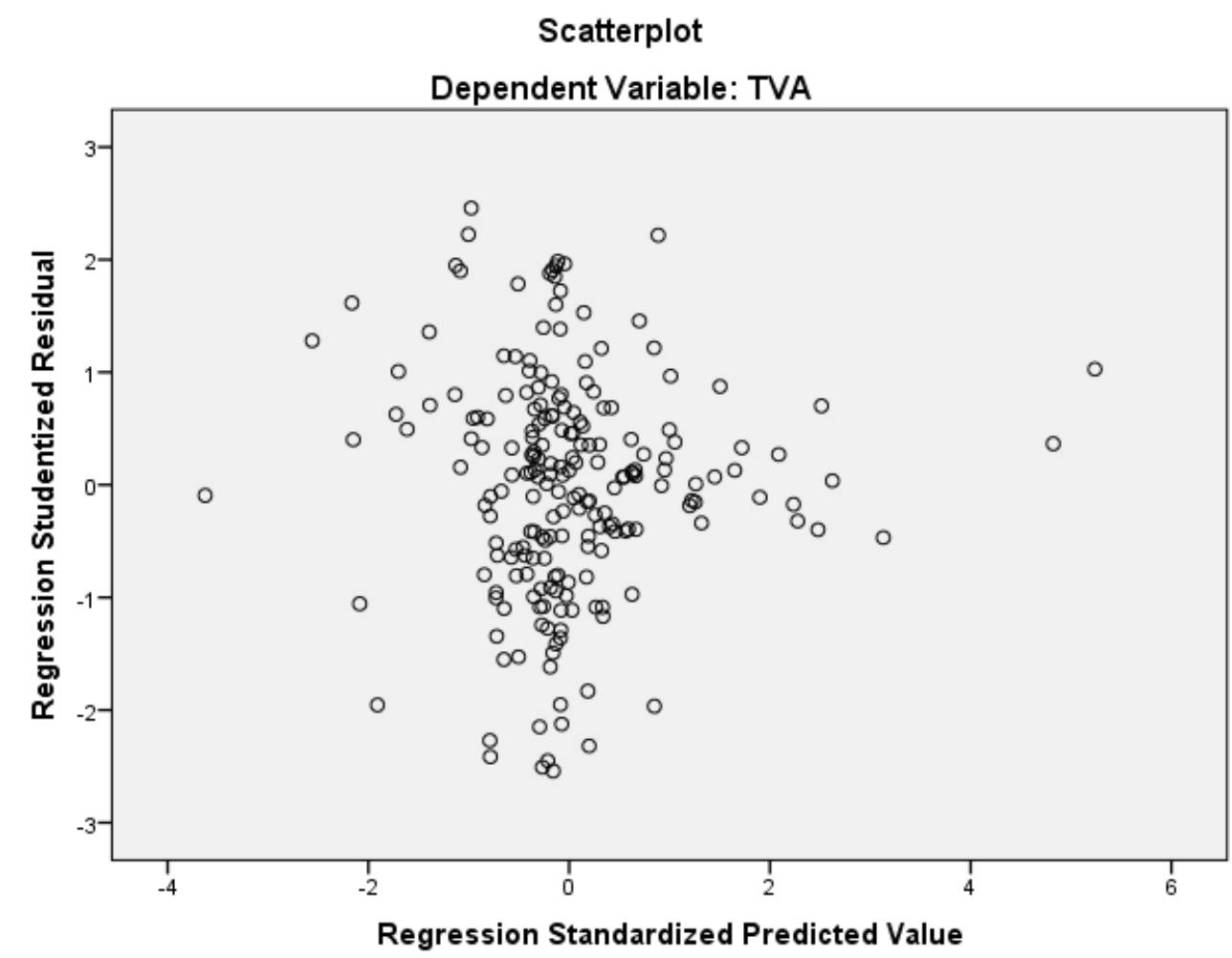

Gambar 1: Hasil Uji Heterokedastisitas (Sumber: Data sekunder diolah, 2020)

Berdasarkan grafik scatterplot, maka dapat dilihat bahwa titik-titik tidak membentuk pola tertentu dan data menyebar secara acak di atas dan di bawah angka 0 pada sumbu Y. Hal ini menunjukkan bahwa tidak terjadi heterokedastisitas pada model regresi yang digunakan pada penelitian ini.

\section{Hasil Pengujian Autokorelasi}

Tabel5: Hasil Uji Autokorelasi

\begin{tabular}{lrrrrr}
\hline Model & $\mathrm{R}$ & $\mathrm{R}$ Square & $\begin{array}{c}\text { Adjusted } \mathrm{R} \\
\text { Square }\end{array}$ & $\begin{array}{l}\text { Std. Error of the } \\
\text { Estimate }\end{array}$ & Durbin-Watson \\
\hline 1 &, $254^{\mathrm{a}}$ &, 064 &, 032 & 1,17071 & 1,983 \\
\hline
\end{tabular}

Sumber: Data sekunder diolah, 2020

Berdasarkan hasil pengujian Durbin-Watson, maka dapat dilihat nilai Durbin-Watson yang didapatkan sebesar 1,983. Hasil tersebut menunjukkan bahwa dU $<$ DW $<4$-dU $(1,822<1,876<$ 2,178 ), di mana dU sebesar 1,822 sedangkan nilai dari 4-dU sebesar 2,178. Hal tersebut menunjukkan bahwa berdasarkan pengujian Durbin-Watson, maka dapat dikatakan bahwa tidak terdapat autokorelasi. 
Hasil Analisis Regresi Berganda

Tabel 6: Hasil Uji Regresi Berganda

\begin{tabular}{|c|c|c|c|c|c|c|}
\hline \multirow[t]{2}{*}{ Mod } & & \multicolumn{2}{|c|}{ Unstandardized Coefficients } & \multirow{2}{*}{$\begin{array}{c}\begin{array}{c}\text { Standardized } \\
\text { Coefficients }\end{array} \\
\text { Beta } \\
\end{array}$} & \multirow[t]{2}{*}{$\mathrm{t}$} & \multirow[t]{2}{*}{ Sig. } \\
\hline & & $\mathrm{B}$ & Std. Error & & & \\
\hline \multirow{8}{*}{1} & (Constant) & $-4,421$ & 13,925 & &,- 317 & ,751 \\
\hline & AKO &,- 178 & ,479 &,- 035 &,- 372 & ,711 \\
\hline & AKI & ,900 & ,379 & ,244 & 2,372 &, 019 \\
\hline & AKP &,- 153 & 800 &,- 020 &,- 191 & ,849 \\
\hline & DPR & 1,761 & 1,395 & ,089 & 1,262 & ,208 \\
\hline & EVA &,- 248 & ,432 &,- 044 &,- 575 &, 566 \\
\hline & SIZE &,- 706 & 3,635 &,- 019 &,- 194 & ,846 \\
\hline & GROW & ,796 & ,739 & ,076 & 1,078 & ,283 \\
\hline
\end{tabular}

Sumber: Data sekunder diolah, 2020

Berdasarkan pada hasil analisis regresi berganda, dapat diketahui bahwa nilai konstanta (a) dari model regresi yang digunakan yaitu sebesar -4,421 yang menyatakan bahwa apabila tidak ada variabel independen maka volume perdagangan saham bernilai negatif sebesar -4,421 dengan koefisien regresi dari setiap variabel independen sebesar $b 1=-0,178, b 2=0,900, b 3=-0,153, b 4=1,761, b 5=-0,248$, $\mathrm{b} 6=-0.706$, dan $\mathrm{b} 7=0.796$. Dengan menggunakan hasil dari analisis regresi linier berganda tersebut, maka hubungan antara variabel independen terhadap variabel dependen dalam model regresi yang digunakan dapat dirumuskan sebagai berikut: TVA $=-4,421-0,178 \mathrm{AKO}+0,900 \mathrm{AKI}-0,153 \mathrm{AKP}+1,761 \mathrm{DPR}-0,248 \mathrm{EVA}-$ 0,706SIZE+0,796GROW + $e$

\section{Hasil Pengujian Hipotesis Hasil Uji Koefisien Determinasi}

Tabel 7: Hasil Uji Koefisien Determinasi

\begin{tabular}{lrrr}
\hline Model & $\mathrm{R}$ & \multicolumn{1}{c}{$\mathrm{R}$ Square } & Adjusted R Square \\
\hline 1 &, $254^{\mathrm{a}}$ &, 064 &, 032 \\
\hline
\end{tabular}

Sumber: Data sekunder diolah, 2020

Jika dilihat dari nilai Adjusted $R$ Square sebesar 0,032, maka hal tersebut menunjukkan bahwa AKO, AKI, AKP, DPR, EVA SIZE dan GROW hanya mampu menjelaskan TVA sebesar 3,2\%. Sisanya sebesar $96.8 \%$ dipengaruhi oleh faktor lainnya yang tidak dimasukkan dalam model regresi pada penelitian ini.

\section{Uji Statistik t}

Tabel 8: Hasil Uji Statistik t

\begin{tabular}{|c|c|c|c|c|c|c|}
\hline \multirow[t]{2}{*}{ Mo } & & \multicolumn{2}{|c|}{ Unstandardized Coefficients } & \multirow{2}{*}{$\begin{array}{c}\begin{array}{c}\text { Standardized } \\
\text { Coefficients }\end{array} \\
\text { Beta }\end{array}$} & \multirow[t]{2}{*}{$\mathrm{t}$} & \multirow[t]{2}{*}{ Sig. } \\
\hline & & $\mathrm{B}$ & Std. Error & & & \\
\hline \multirow{8}{*}{1} & (Constant) & $-4,421$ & 13,925 & &,- 317 & ,751 \\
\hline & $\mathrm{AKO}$ &,- 178 & ,479 &,- 035 &,- 372 & ,711 \\
\hline & AKI & ,900 & 379 & ,244 & 2,372 & ,019 \\
\hline & AKP &,- 153 & ,800 &,- 020 &,- 191 & ,849 \\
\hline & DPR & 1,761 & 1,395 &, 089 & 1,262 & 208 \\
\hline & EVA &,- 248 & ,432 &,- 044 &,- 575 & ,566 \\
\hline & SIZE &,- 706 & 3,635 &,- 019 &,- 194 & ,846 \\
\hline & GROW & ,796 & ,739 &, 076 & 1,078 & ,283 \\
\hline
\end{tabular}

Sumber: Data sekunder diolah, 2020 


\section{Hasil Uji Statistik F}

\begin{tabular}{rlrrrrr}
\multicolumn{7}{c}{ Tabel 9: Hasil Uji Statistik F } \\
\hline Model & Sum of Squares & df & Mean Square & F & Sig. \\
\hline \multirow{4}{*}{1} & Regression & 18,930 & 7 & 2,704 & 1,973 &, $060^{\mathrm{b}}$ \\
& Residual & 275,485 & 201 & 1,371 & & \\
& Total & 294,414 & 208 & & & \\
\hline
\end{tabular}

Sumber: Data sekunder diolah, 2020

Hasil pengujian statistik $\mathrm{F}$ menunjukkan bahwa nilai signifikan sebesar 0,060 lebih besar dibandingkan tingkat signifikansi sebesar 0,05. Hasil pengujian tersebut juga menunjukkan bahwa nilai Fhitung lebih besar dari nilai Ftabel $(1,973<2,15)$. Berdasarkan pada hasil tersebut, maka dapat dikatakan bahwa kandungan informasi laporan arus kas (arus kas operasi, arus kas investasi, arus kas pendanaan), Dividend Payout Ratio, Economic Value Added, Size dan Growth tidak secara simultan atau bersama-sama memiliki pengaruh terhadap volume perdagangan saham.

\section{Pengaruh Kandungan Informasi Laporan Arus Kas Terhadap Volume Perdagangan Saham}

Berdasarkan pada hasil penelitian yang telah dilakukan nilai signifikan arus kas operasi sebesar 0,711 lebih besar dari nilai $\alpha$ senilai 0,05. Nilai t-hitung untuk variabel arus kas operasi sebesar -0,372. Nilai tersebut lebih kecil dibandingkan dengan nilai t-tabel yaitu sebesar 1,975. Dengan demikian, maka dapat disimpulkan bahwa arus kas operasi tidak berpengaruh signifikan terhadap volume perdagangan saham. Berdasarkan hasil tersebut, maka hipotesis 1a ditolak. Tidak terbuktinya hipotesis 1a tersebut arus kas operasi yang tidak berpengaruh terhadap volume perdagangan saham menunjukkan bahwa perusahaan yang ada dalam sektor manufaktur tersebut mengalami naik turun kas bersih yang diperoleh dari aktivitas operasi setiap tahunnya tidak dapat memengaruhi para investor untuk berinvestasi pada perusahaan. Hal tersebut dapat dilihat melalui tinggi rendahnya volume perdagangan saham. Selain itu, tidak berpengaruhnya arus kas operasi terhadap volume perdagangan saham dapat disebabkan oleh kecilnya penerimaan kas maupun dari pelanggan dan lainnya.

Hasil penelitian ini sejalan dengan hasil penelitiannya (Bastomi, 2014), (Afrinta, 2013) yang menemukan bahwa Arus Kas dari aktivitas operasi perusahaan tidak memiliki pengaruh yang signifikan terhadap volume perdagangan. Hal ini menunjukkan bahwa kecilnya penerimaan kas dari pelanggan dan penerimaan kas dari aktivitas operasi lainnya. Selain itu, rendahnya arus kas aktivitas operasi juga dipengaruhi oleh perusahaan yang tidak mampu untuk menekan pembayran kas kepada pemasok maupun karyawan. Para investor dan calon investor sebelum melakukan investasi melihat arus kas dari aktivitas oeprasi suatu perusahaan. Karena aktivitas operasi adalah aktivitas penghasil utama pendapatan perusahaan dan merupakan indicator yang menentukan apakah dari operasinya perusahaan dapat menghasilkan arus kas yang cukup untuk melunasi pinjaman, memelihara kemampuan operasi perusahaan, membayar deviden dan melakukan investasi baru tanpa mengandalkan pendanaan dari luar.

Arus kas investasi memiliki nilai signifikan sebesar 0,019 lebih kecil dari nilai $\alpha$ senilai 0,05 . Nilai thitung sebesar 2,372 yang lebih besar dari ttabel sebesar 1,975, sehingga hasil olah data tersebut dapat disimpulkan bahwa arus kas investasi berpengaruh signifikan terhadap volume perdagangan saham, maka hipotesis $1 \mathrm{~b}$ diterima. Hasil yang menunjukkan arus kas investasi berpengaruh signifikan terhadap volume perdagangan saham tersebut diartikan bahwa arus kas bersih investasi yang dihasilkan oleh perusahaan yang ada dalam sektor manufaktur dapat mencerminkan tingkat kemampuan perusahaan dalam keadaan tetap tumbuh di masa yang akan datang. Hal tersebut memberikan sinyal positif kepada para investor tentang jaminannya di masa yang akan datang. Selain itu, hasil arus kas investasi yang berpengaruh signifikan terhadap volume perdagangan saham menunjukkan bahwa para investor memperhatikan hasil dari investasi jangka panjang maupun pendek serta penjualan aktiva tetap yang dilakukan perusahaan. Kebijakan perusahaan melakukan untuk melakukan investasi jangka panjang dan pendek membuat para investor tertarik membeli saham perusahaan dengan harapan agar dapat memperoleh keuntungan. Hasil penelitian ini serupa dengan hasil penelitian yang dilakukan oleh (Afrinta, 2013) yang menunjukkan bahwa arus kas investasi 
memiliki pengaruh signifikan terhadap volume perdagangan saham. Hasil penelitian ini juga sejalan dengan hasil penelitian yang dilakukan oleh (Bastomi, 2014) yang menunjukkan bahwa investor beranggapan dari arus kas investasi dapat memberikan dampak signifikan atas pengembalian yang diharapkan. Arus kas investasi juga mencerminkan tingkat kemampuan perusahan dalam keadaan tetap tumbuh dimasa dating. Hal tersebut memberikan sinyal yang positif kepada investor dan calon investor akan jaminan investasinya di masa yang akan datang.

Arus kas pendanaan memiliki nilai signifikan sebesar 0,849. Nilai thitung sebesar -1,191 yang di mana angka tersebut lebih kecil dari t-tabel sebesar 1,975, sehingga hasil tersebut dapat disimpulkan bahwa arus kas pendanaan tidak berpengaruh signifikan terhadap volume perdagangan saham, maka hipotesis 1c ditolak. Hasil yang menunjukkan bahwa arus kas pendanaan tidak berpengaruh signifikan terhadap volume perdagangan saham diartikan bahwa keputusan pendanaan tidak direspon oleh banyak investor dan dapat dikatakan bukan sebagai satu-satunya bahan pertimbangan investasi sehingga investor lebih memperhatikan faktor lain dalam pengambilan keputusan investasinya. Investor berpendapat bahwa aktivitas dari arus kas pendanaan seperti penerbitan utang, pinjaman kepada bank maupun kepada pihak lain dan pembayaran dividen bukan sebagai bahan pertimbangan utama untuk mengambil keputusan dalam membeli saham karena pembayaran-pembayaran tersebut secara besar.Hasil penelitian ini sejalan dengan hasil penelitian yang dilakukan oleh (Afrinta, 2013) , (Bastomi, 2014).

\section{Pengaruh Dividend Payout Ratio (DPR) Terhadap Volume Perdagangan Saham}

Berdasarkan hasil penelitian yang telah dilakukan, nilai signifikansi yang didapatkan untuk variabel Dividend Payout Ratio (DPR) sebesar 0,208 lebih kecil dari nilai $\alpha$ 0,05. Dengan nilai thitung sebesar 1,262 yang menunjukkan bahwa t-hitung > t-tabel $(1,262<1,975)$ maka hasil tersebut dapat disimpulkan bahwa Dividend Payout Ratio (DPR) tidak berpengaruh signifikan terhadap volume perdagangan saham sehingga hipotesis kedua diterima.

Hasil yang menunjukkan Dividend Payout Ratio (DPR) tidak berpengaruh signifikan terhadap volume perdagangan saham menunjukkan diakibatkan karena kebijakan dari sebagian besar perusahaan untuk tidak membagikan deviden sehingga dividend payout ratio tidak berpengaruh terhadap keputusan investor. Dividen yang mengalamai peningkatan dan penurunan secara drastic akan berpengaruh langsung terhadap DPR yang dihasilkan.

Secara teori pembagian deviden memberikan sinyal positif kepada para investor akan prospek saham karena mengindikasikan kemampuan perusahaan untuk menghasilkan keuntungan. Berdasarkan data penelitian dilihat bahwa Dividend Payout Ratio perusahaan manufaktur yang terdaftar di Bursa Efek Indonesia menunjukkan sebagaian besar perusahan tidak membayar dividen kepada pemegang saham.

Hal ini terlihat dari sebagian besar sampel data, banyak perusahaan yang mengalami kerugian dan tidak membayarkan dividen kepada pemegang saham sehingga meninmbulkan reaksi yang negatif terhadap investor dan volume perdangan saham pada khususnya. Hasil penelitian ini sejalan dengan hasil penelitian (Safitri et al., 2018), yang menyatakan bahwa DPR tidak mempunyai pengaruh signifikan terhadap volume perdagangan saham.

\section{Pengaruh Economic Value Added (EVA) Terhadap Volume Perdagangan Saham}

Hasil penelitian yang telah dilakukan menunjukkan nilai signifikansi EVA sebesar 0,566, nilai tersebut lebih besar dari $\alpha 0,05$. Dengan nilai t-hitung sebesar $-0,575$ yang lebih kecil dari nilai t-tabel sebesar 1,975. Berdasarkan hasil tersebut, maka dapat disimpulkan bahwa Economic Value Added (EVA) tidak berpengaruh terhadap volume perdagangan saham sehingga hipotesis ketiga ditolak.

Hasil penelitian tersebut menunjukkan bahwa EVA bukan faktor penentu yang mempengaruhi volume perdagangan saham. Hal tersebut dibuktikan, dari tidak berpengaruhnya EVA terhadap volume perdagangan saham. sehingga informasi EVA tidak menjadi daya tarik dan minat investor dalam berinvestasi saham sehingga respon terhadap volume perdagangan saham tidak kuat.

Hasil yang menunjukkan bahwa EVA tidak berpengaruh terhadap volume perdagangan saham dapat diartikan sebagian atau rata-rata nilai EVA perusahan memiliki nilai negatif (EVA $<0$ ) yang berarti tidak terjadi proses nilai tambah di mana perusahaan tidak mampu menghasilkan tingkat pengembalian operasi yang melebihi biaya modal. Dengan kata lain, walaupun perusahaan mampu 
menghasilkan laba bersih yang tinggi, tetapi perusahaan sedang mengalami penurunan nilai. Hal ini menjadi salah satu reaksi negatif investor dalam melakukan investasi. Hal lain juga dapat disebabkan oleh karena mayoritas investor pada perusahaan sektor manufaktur yang membeli saham suatu perusahaan untuk kemudian nantinya dijual kembali. Dengan keadaan mayoritas investor melakukan investasi jangka pendek, maka EVA yang merupakan metode yang menjadi fokus pada prosepek jangka panjang menjadi tidak berpengaruh secara signifikan. Sehingga tidak terbukti EVA mempunyai kandungan informasi dan tidak dijadikan sebagai bahan pertimbangan oleh investor dalam membeli saham. Hasil penelitian ini sejalan dengan penelitian yang dilakukan oleh (Safitri et al., 2018) \& (Ayuningrum, 2013) yang menyatakan bahwa EVA tidak mempunyai pengaruh signifikan terhadpa volume perdagangan saham.

\section{Variabel Kontrol}

Penelitian ini juga memasukkan variabel kontrol untuk mengakui bahwa AKO, AKI, AKP, DPR, dan EVA mempunyai keterikatan dengan beberapa faktor yang meliputi SIZE dan GROWTH. Hasil statistic menunjukkan bahwa SIZE memiliki nilai signifikansi sebesar 0,846 dan t-hitung sebesar 1,94. Hal ini menunjukkan bahwa SIZE tidak mengakui adanya keterikatan dengan AKO, AKI, AKP, DPR, dan EVA terhadap volume perdagangan saham.

Hal ini menunjukkan bahwa perusahaan yang besar yang sudah wellestablished akan lebih mudah memperoleh modal dipasar modal dibandingkan dengan perusahaan kecil. Kemudahan akses tersebut berarti perusahaan besar memiliki flesibilitas yang lebih besar pula. Adanya dua hasil penelitian yang berbeda membuat investor tidak memperhatikan SIZE (ukuran perusahaan) dalam keputusan investasi pada saham. Yang mana ukuran perusahan yang besar tidak memberikan gambaran bahwa perusahan aktif memperdagangkan sahamnya di pasar modal.Maka ukuran perusahan (SIZE) tidak berpengaruh pada volume perdagangan sebagai varibel yang memiliki keterikatan dengan variabel-variabel independen yang ada. Hasil penelitian ini sejalan dengan penelitian yang dilakukan oleh (Aisah \& Mandala, 2016).

Sedangkan, GROWTH memiliki nilai signifikansi sebesar 0,283 dan t-hitung sebesar 1,078. Selain itu, berkaitan dengan pertumbuhan perussahaan (GROWTH) menunjukkan bahwa tidak mengakui adanya keterikatan dengan AKO, AKI, AKP, DPR, dan EVA terhadap volume perdagangan saham. Hal ini menunjukkan bahwa peningkatan atau penurunan total asset yang dimiliki oleh perusahaan tidak memberikan bukti bahwa perusahaan akan aktif melakukan perdagangan saham di pasar modal. Maka pertumbuhan perusahaan (GROWTH) tidak berpengaruh terhadap volume perdangan sebagai variabel kontrol dari variabel-variabel indepen dalam penelitian ini.

\section{Penutup}

\subsection{Kesimpulan}

Penelitian ini bertujuan untuk menguji pengaruh dari kandungan informasi pada laporan arus kas perusahaan, dividend payout ratio, economic value added, dan menggunakan proksi ukuran perusahaan (size) dan pertumbuhan perusahaan ( growth) sebagai variabel kontrol. Hasil penelitian ini menjukkan bahwa: Informasi arus kas investasi berpengaruh signifikan terhadap volume perdagangan saham. Hal tersebut memberikan sinyal positif kepada para investor tentang jaminannya di masa yang akan datang. Selain itu, hasil arus kas investasi yang berpengaruh signifikan terhadap volume perdagangan saham menunjukkan bahwa para investor memperhatikan hasil dari investasi jangka panjang maupun pendek serta penjualan aktiva tetap yang dilakukan perusahaan.

Sedangkan, Informasi arus kas operasi, arus kas pendanaan, dividend payout ratio, dan economic value added tidak berpengaruh signifikan terhadap volume perdagangan saham perusahaan manufaktur yang terdaftar di Bursa Efek Indonesia (BEI) dengan Size dan Growth sebagai variabel kontrol tidak berpengaruh terhadap volume perdagangan saham. Hal ini menunjukkan bahwa SIZE dan GROWTH tidak mengakui adanya keterikatan dengan AKO, AKI, AKP, DPR, dan EVA terhadap volume perdagangan saham. 


\subsection{Keterbatasan Penelitian}

Berdasarkan kesimpulan serta keterbatasan pada penelitian ini yaitu:

1. Bagi para penanam modal seperti investor dan calon investor, diharapkan dalam menilai kinerja perusahaan yang berkaitan dengan keputusan investasi dalam lebih menggali informasi yang lebih akurat yang berkaitan dengan laporan arus kas, kebijakan dividen, Economic Value Added (EVA) . Sehingga, dapat menggunakan metode penilaian kinerja keuangan yang tepat berdasarkan tujuan dan kebutuhan investasi masing-masing agar dapat mengambil keputusan investasi yang tepat.

2. Untuk dapat meningkatkan kepercayaan investor terhadap perusahaan, perusahan diharapkan dapat mepublikasikan informasi yang andal dan lengkap yang dapat dijadikan dasar oleh investor dalam mengambil keputusan berkaitan dengan arus kas, investasi, pendanaan yang berkaitan dengan pembelian dan penjualan volume perdagangan saham perusahan.

\subsection{Saran}

Saran bagi penelitian selanjutnya, diharapkan dapat menambah variabel independen berupa kualitas laba dan corporate social responsibility variabel lainnya yang dapat mempengaruhi volume perdagangan saham serta menambah sampel penelitian. Dengan demikian, penelitian selanjutnya dapat memberikan hasil penelitian pengaruh terhadap volume perdagangan saham yang lebih baik.

\section{Daftar Pustaka}

Afrinta, R. (2013). Pengaruh Laba Akuntansi, Total Arus Kas, Komponen Arus Kas, Return on Equity Terhadap Volume Perdagangan Saham Pada Perusahaan Pertambangan Yang Terdaftar Di Bursa Efek Indonesia Tahun 2010-2013. Jom Fekon Universitas Riau, 1(1), 69-73. https://doi.org/10.11113/jt.v56.60

Aisah, A., \& Mandala, K. (2016). Pengaruh Return on Equity, Earning Per Share, Firm Size Dan Operating Cash Flow Terhadap Return Saham. E-Jurnal Manajemen Universitas Udayana, 5(11), 254691.

Amethisa, G. (2008). Pengaruh Economic Value Added, Current Ratio dan Dividend Payout Ratio Terhadap Trading Volume Activity Dengan Harga Saham Sebagai Variabel Moderasi. Accounting Analysis Journal, 4(672013167), 0-18.

Anggraini, V., Hartini, T., Si, M., Wijaya, T., Kom, S., Manajemen, J., \& Mdp, S. (2013). Pengaruh Harga Saham, Volume Perdagangan dan Ukuran Perusahaan terhadap Bid Ask Spread pada Perusahaan Food and Beverage yang Terdaftar di Bursa Efek Indonesia. STIE MDP Journal, $1(1), 1-7$.

Ayuningrum, S. (2013). Pengaruh Informasi Laporan Arus Kas, Deviden Payout Ratio (DPR), Economic Value Added (EVA) Terhadap Volume Perdagangan Saham Di Bursa Efek Indonesia. Jom Fekon Universitas Riau, 1(1), 69-73. https://doi.org/10.11113/jt.v56.60

Azhar, A., Rofika, \& Rohayati, L. (2009). Pengaruh Informasi Arus Kas dan Laba Akuntansi terhadap Volume Perdagangan Saham pada Perusahaan Manufaktur yang Terdaftar di Bursa Efek Indonesia.

Azhar et al. (2009). Pengaruh Informasi Arus Kas dana Laba Akuntansi terhadap Volume Perdagangan Saham pada Perusahaan Manufaktur yang Terdaftar di Bursa Efek Indonesia. 4(2), 1-15. http://www.albayan.ae

Bastomi, Y. (2014). Pengaruh Informasi Laporan Arus Kas Terhadap Volume Perdagangan Saham pada Perusahaan Food an Beverage yang Tercatat di Bursa Efek Indonesia. Jurnal Akuntansi Unesa, 1-23.

Hidayah. (2010). Pengaruh Informasi Arus Kas, Laba Kotor, Ukuran Perusahaan, Volume Perdagangan Saham Terhadap Expected Return. 1-30. https://doi.org/10.1007/s10584-013-06992

Hilma, M. (2014). Pengaruh Informasi Laba Akuntansi Dan Arus Kas Terhadap Volume Perdagangan Saham. September.

Kurniawansyah, D., \& Kurnianto, S. (2018). Teori Agency Dalam Pemikiran Organisasi ; Pendekatan Positivist Dan Principle-Agen. Jurnal Riset Akuntansi Dan Bisnis Airlangga, 3(2), 435-446. 
https://doi.org/10.31093/jraba.v3i2.122

Melati, M., \& Nurwulandari, A. (2013). Analisis Reaksi Pasar terhadap Corporate Action pada Perusahaan Bertumbuh dan Tidak Bertumbuh di Bursa Efek Indonesia. Oikonomia 13(2) - Melati Dan Nurwulandari, 13(2), 1-25.

Novalia, F., \& Nindito, M. (2016). Pengaruh Konservatisme Akuntansi Dan Economic Value Added Terhadap Penilaian Ekuitas Perusahaan. Jurnal Wahana Akuntansi, 11(2), 1. https://doi.org/10.21009/10.21.009/wahana.011/2.1

Rajagukguk, L., Ariesta, V., \& Pakpahan, Y. (2019). Analisis Pengaruh Profitabilitas, Ukuran Perusahaan, Keputusan Investasi, dan Kebijakan Utang Terhadap Nilai Perusahaan. Jurnal Inspirasi Bisnis Dan Manajemen, 3(1), 77. https://doi.org/10.33603/jibm.v3i1.2079

Safitri, R. H., Kosim, A., Nurullah, A., Indah, S., \& Andini, P. (2018). Pengaruh Informasi Laporan Arus Kas, Dividend Payout Ratio ( Dpr ), Economic Value Added ( Eva ) Terhadap Volume. 6(2), 117-130. https://doi.org/10.24964/ja.v6i2.659

Susilowati, E., \& Sinaga, H. (2019). Pengaruh Laba Bersih, Arus Kas Dan Dividen Tunai Terhadap Volume Perdagangan Saham Pada Perusahaan Publik Sektor Barang Dan Konsumsi Di BEI. JMK (Jurnal Manajemen Dan Kewirausahaan), 4(1), 32. https://doi.org/10.32503/jmk.v4i1.356

Sutriasih, Emi. Putra, I Gede Cahyadi. Suryawathy, I. G. A. (2013). Pengaruh Informasi Laba Bersih, Arus Kas, Dan Publikasi Dividen Paa Volume Perdagangan Perusahaan Manufaktur Di Bursa Efek Indonesia. Jurnal Ilmiah Akuntansi Dan Humanika, 3(1), 1055-1070. file:///C:/Users/youhe/Downloads/kdoc_o_00042_01.pdf

Sutriasih, E., Gede, I., \& Gusti, I. (2013). Pengaruh Informasi Laba Bersih, Arus Kas dan Publikasi Deviden Pada Volume Perdagangan Perusahaan Manufaktur Di Bursa Efek Indonesia. 3, 10551070.

Zahroh, S. (2009). Pengaruh Dividend Payout Ratio, Volume Perdagangan Saham, Ukuran Perusahaan (Firm Size), Debt To Equity Ratio, Price Earning Ratio Terhadap Return Saham Pada Perusahaan Yang Melakukan Pembayaran Dividend Kas di Bursa Efek Indonesia Periode 2004-2007. Jurnal Jurusan Manajemen Universitas Islam Negeri Syarif Hidayayullah Jakarta, 2(5), 255. ??? 